\title{
Factors affecting fasting serum C-peptide levels in Micronesians: comparison with a Caucasoid population
}

\author{
P. Garcia-Webb ${ }^{1}$, P.Zimmet ${ }^{2}$, A. Bonser ${ }^{1}$, H. King ${ }^{2}$ and S. Bottomley ${ }^{1}$ \\ ${ }^{1}$ Department of Clinical Biochemistry, University of Western Australia, Perth, and \\ ${ }^{2}$ WHO Collaborating Centre for the Epidemiology of Diabetes Mellitus, Royal Southern Memorial Hospital, Melbourne, Victoria, Australia
}

\begin{abstract}
Summary. Fasting serum C-peptide immunoreactivity was determined on Nauruans, a Micronesian population with a high prevalence of diabetes. In Micronesian subjects neither age nor gender had a significant effect on fasting serum C-peptide. In non-diabetic subjects, as has been shown previously for Caucasiod subjects, both obesity and fasting plasma glucose levels were determinants of fasting serum C-peptide. Obesity was the major determinant. Taken overall, mean fasting serum C-peptide increased then possibly fell in subjects grouped by increasing 2 -h post-glucose plasma glucose levels. Mean fasting serum C-peptide in newly-diagnosed diabetic subjects was greater than that in non-diabetic subjects with a
\end{abstract}

similar degree of obesity, supporting the concept that the transition to diabetes may be associated with an increase in insulin resistance. The data for non-diabetic subjects were compared with serum C-peptide measured in the same laboratory on samples from a Caucasoid population in Busselton, Western Australia. There was no difference in fasting serum C-peptide level between Micronesian and Caucasoid subjects approximately matched for obesity and fasting plasma glucose levels.

Key words: C-peptide, obesity, fasting, glucose, Micronesian, Caucasoid, Type 2 diabetes.
In Caucasoid subjects, mean fasting serum C-peptide immunoreactivity (CPR) levels have been shown to be increased by both increasing obesity and increasing fasting plasma glucose concentration [1]. In non-Caucasoid subjects with a high prevalence of Type 2 (non-insulin-dependent) diabetes, evidence suggests that fasting plasma glucose concentration has little effect on fasting insulin secretion. Fasting insulin levels are relatively unchanged by deteriorating glucose tolerance in Pima Indians [2], Polynesians and Micronesians [3].

The measurement of serum CPR is now generally held to be a better index of insulin secretion than the measurement of serum insulin. Arterial CPR correlates strongly with splanchnic C-peptide output in both normal subjects and subjects with Type 2 diabetes [4]. The aim of this study was to investigate the effects of such variables as age, sex, obesity, fasting plasma glucose concentration and deteriorating glucose tolerance on fasting serum CPR levels in the Micronesian population of Nauru. In addition, the study provided an opportunity to compare fasting serum CPR levels in Micronesian and Caucasoid subjects.

\section{Subjects and methods}

\section{Subjects}

Samples for CPR measurement were taken from a randomly-selected group of subjects attending an epidemiological survey of the whole adult Micronesian population of Nauru. Overall, 1583 subjects attended the survey, giving a response rate of approximately $80 \%$. The present randomly-selected study group consisted of 274 females and 210 males with ages ranging from 19 to 75 years. The mean age of the group was 36 years. The distribution of age, sex and obesity in the Cpeptide study group was similar to that in the whole population. Data from the Micronesian subjects were compared with data obtained from 928 fasting, non-diabetic Caucasoid subjects attending a Busselton survey [1].

\section{Methods}

Serum CPR was measured using a double-antibody radioimmunoassay based on the antibody M1230 [5]. The antibody had 11\% crossreactivity with proinsulin [6]. The lower limit of sensitivity was $0.02 \mathrm{nmol} / 1$ and the batch-to-batch coefficient of variation was consistently $<5 \%$, at a mean of approximately $0.5 \mathrm{nmol} / 1$. Samples were stored frozen for a minimum period before transfer to Australia and then stored at $-70^{\circ} \mathrm{C}$ for a maximum of 4 months before analysis. 
Table 1. Mean body mass index and fasting serum C-peptide and plasma glucose levels in diabetic and non-diabetic Micronesian subjects

\begin{tabular}{lccc}
\hline & $\begin{array}{l}\text { Non-diabetic subjects } \\
(n=364)\end{array}$ & $\begin{array}{l}\text { New diabetic subjects } \\
(n=56)\end{array}$ & $\begin{array}{l}\text { Known diabetic subjects } \\
(n=64)\end{array}$ \\
\hline Body mass index & $33.2(21.9-50.2)$ & $34.0(22.3-51.6)$ & $33.1(23.0-47.0)$ \\
Fasting serum C-peptide $(\mathrm{nmol} / \mathrm{l})$ & $0.57(0.26-1.28)$ & $0.68^{\mathrm{a}}(0.31-1.51)$ & $0.60(0.32-1.13)$ \\
Fasting plasma glucose $(\mathrm{mmol} / \mathrm{l})$ & $5.2(4.0-6.8)$ & $9.5^{\mathrm{b}}(4.3-20.9)$ & $12.5^{\mathrm{b}}(6.1-25.6)$ \\
\hline
\end{tabular}

Results expressed as mean, with 'range' (mean $\pm 2 \mathrm{SD}$ ) in parentheses, calculated on log-transformed data.

a $p=0.002$, mean significantly greater than for non-diabetic subjects; ${ }^{b} p<0.0005$; mean significantly greater than for non-diabetic subjects

Table 2. Pearson correlation coefficients for the variables fasting serum C-peptide, fasting plasma glucose, age and body mass index in diabetic and non-diabetic Micronesian subjects

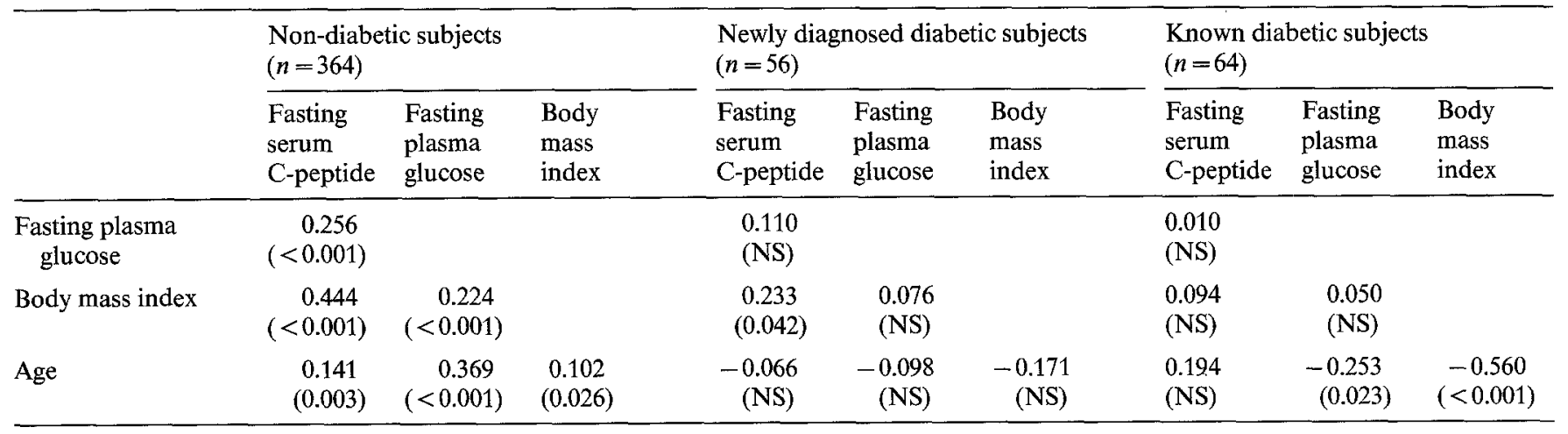

$p$ values given in parentheses

The samples from the Micronesian subjects were measured 3 years after the Busselton samples. Laboratory quality control data suggest no alteration in the accuracy of CPR analyses during that time.

Plasma glucose was measured by glucose oxidase using a Yellow Springs Analyser (Ohio, USA). Body mass index (weight $[\mathrm{kg}] /$ height $[\mathrm{m}]^{2}$ ); and mid-triceps fat-fold thickness were measured as indices of obesity. Preliminary statistical analysis of the data showed that results, using body mass index, were very similar to data using fat-fold thickness. Body mass index alone was used as the index of obesity, subjects being taken as obese if body mass index equalled or exceeded 27 for men and 25 for women.

\section{Statistical analysis}

Computer analysis of the data was performed using the Statistical Package for Social Sciences [7]. The distributions of arithmetic data for serum CPR, plasma glucose and body mass index were non-Gaussian. These data were submitted to $\log _{10}$ transformation before analyses requiring the assumption of normal distribution including mean and SD. Classification of abnormal glucose tolerance was based on National Diabetes Data Group criteria [8], diabetes mellitus being diagnosed if plasma glucose concentration was $11.1 \mathrm{mmol} / 1(200 \mathrm{mg} /$ $100 \mathrm{ml}$ ) or greater, $2 \mathrm{~h}$ after a 75 -g oral glucose load. All known diabetic subjects were included in the diabetic category. Subjects found to be diabetic for the first time as a result of the survey are referred to here as newly-diagnosed diabetic patients

\section{Results}

Mean \pm 2 SD for fasting CPR, plasma glucose and body mass index for all subjects were $0.59 \mathrm{nmol} / 1(0.27-1.29)$, $0.63 \mathrm{mmol} / 1(2.8-13.9)$ and 33.3 (22.2-49.9), respectively. Mean fasting serum CPR levels for both female and male subjects were $0.59 \mathrm{nmol} / 1$. Statistical analysis of the data was similar for female and male subjects; the data reported here refer to the group as a whole.

The mean fasting serum CPR level in subjects known to have diabetes was similar to that in non-diabetic subjects (Table 1). However, in newly diagnosed diabetic subjects the mean fasting serum CPR level was significantly greater than that in non-diabetic subjects. The three groups had similar means of body mass index. Mean \pm SEM age for non-diabetic subjects (22.1 \pm 0.6 years), was less than that for new diabetic subjects ( $44.3 \pm 1.8$ years) and known diabetic subjects ( $48.7 \pm 1.4$ years) $(p<0.0005$ for both). The correlations between CPR and other variables are shown in Table 2.

In non-diabetic subjects, the correlation of age with serum CPR was very weak $\left(r^{2}<0.02\right)$. Age also showed a positive correlation with plasma glucose levels. The partial coefficient of age and serum CPR was not significant when the effects of plasma glucose on the relationship were taken into account $(r=0.06, p=0.14)$.

Further statistical analyses were performed to study the interrelationships between the variables fasting serum CPR, body mass index and fasting plasma glucose levels in non-diabetic subjects. The partial correlation coefficent of serum CPR with plasma glucose was significant $(r=0.17, p<0.001)$ although $r^{2}$ was small. Multiple regression analysis was performed with serum CPR levels as the dependent variable. Adding the variable plasma glucose to the equation, after the variable body mass index, had a significant effect $(p=0.005)$, suggesting that the variables body mass index and plasma glucose were independently correlated with serum CPR. Serum CPR results were then submitted to multi- 
Table 3. Serum C-peptide levels in non-diabetic Micronesian subjects grouped by body mass index and plasma glucose levels

\begin{tabular}{ccccc}
\hline & $\begin{array}{l}\text { No. of } \\
\text { subjects }\end{array}$ & $\begin{array}{l}\text { Fasting serum } \\
\text { C-peptide (nmol/1) }\end{array}$ \\
\cline { 4 - 5 } & & & Mean & 'Range' \\
\hline Body mass index $<30$ & & & \\
Plasma glucose $<5.0 \mathrm{mmol} / 1$ & 43 & 0.40 & $0.17-0.98$ \\
& $5.0-5.4 \mathrm{mmol} / 1$ & 36 & 0.45 & $0.20-0.99$ \\
$>5.4 \mathrm{mmol} / 1$ & 19 & 0.57 & $0.31-1.04$ \\
Body mass index $30-36$ & & & \\
Plasma glucose $<5.0 \mathrm{mmol} / 1$ & 44 & 0.54 & $0.26-1.10$ \\
& $5.0-5.4 \mathrm{mmol} / 1$ & 48 & 0.61 & $0.28-1.34$ \\
$>5.4 \mathrm{mmol} / 1$ & 49 & 0.62 & $0.32-1.19$ \\
Body mass index $>36$ & & & \\
Plasma glucose $<5.0 \mathrm{mmol} / 1$ & 26 & 0.66 & $0.33-1.30$ \\
& $5.0-5.4 \mathrm{mmol} / 1$ & 37 & 0.69 & $0.33-1.45$ \\
$>5.4 \mathrm{mmol} / 1$ & 51 & 0.69 & $0.39-1.24$ \\
\hline
\end{tabular}

Results expressed as mean and 'range' (mean $\pm 2 \mathrm{SD}$, calculated on log-transformed data). Groups were selected to ensure that the numbers of subjects per set were approximately equal

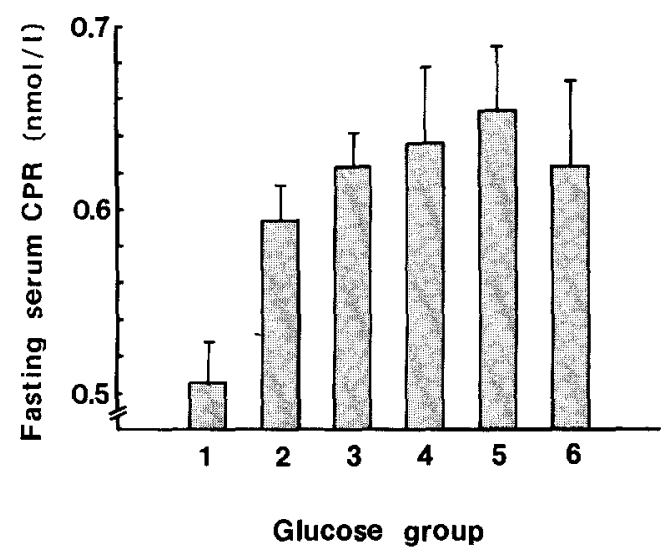

Fig. 1. Mean $\pm S E M$ fasting serum C-peptide immunoreactivity (CPR) for Micronesian subjects grouped by plasma glucose levels $2 \mathrm{~h}$ after a 75 -g glucose drink. Glucose groups are (1) $<5.6 \mathrm{mmol} / 1$; (2) $5.6-7.7 \mathrm{mmol} / 1$; (3) $7.8-11.0 \mathrm{mmol} / \mathrm{l}$; (4) $11.1-15.5 \mathrm{mmol} / 1$; (5) $15.6-22.1 \mathrm{mmol} / 1$; (6) $>22.1 \mathrm{mmol} / \mathrm{l}$. Analysis was performed on log-transformed data. One-way analysis of variance, $F=4.7$, $p=0.0003$

ple analysis of variance (Table 3). An increase in either body mass index or plasma glucose levels resulted in an increase in mean CPR ( $p<0.00001$ and 0.005 for body mass index and glucose, respectively). Again, the variables body mass index and plasma glucose acted independently of each other $(p=0.19$ for the hypothesis that they did not act independently).

Mean fasting serum CPR increased when all subjects were grouped by increasing plasma glucose levels $2 \mathrm{~h}$ after $75 \mathrm{~g}$ glucose load (Fig. 1). The increase was significant when analysed by one-way analysis of variance $(p=0.0003)$. There was a tendency for fasting CPR to fall in the subjects with the highest 2-h plasma glucose levels. This tendency was examined by multiple regression analysis. The dependent variable was serum CPR and the independent variables were $2-\mathrm{h}$ plasma glucose and $(\mathrm{g}-\mathrm{x})^{2}$, where $\mathrm{g}$ is the 2-h plasma glucose result for an individual and $\mathrm{x}$ is the mean 2-h plasma glucose level. The addition of $(\mathrm{g}-\mathrm{x})^{2}$ into the regression resulted in a significant increase in the multiple regression coefficient $(F=4.4, p=0.036)$. However, there was a wide scatter of results, and the final multiple correlation coefficient was only 0.160 . The quadratic equation fitted in the multiple regression analysis had a maximum equivalent to a 2-h plasma glucose level of $20.5 \mathrm{mmol} / \mathrm{l}$.

Data from the non-diabetic Nauru Micronesian subjects were compared with data from a non-diabetic Caucasoid population studied at Busselton [1]. As a group, the Micronesian subjects were more obese than the Caucasoid subjects. It was not possible to match subjects individually for obesity. Instead a subset of each population was studied with limits arbitrarily set to maximize the similarity between the two groups. There were no differences between the mean fasting serum CPR levels in the two plasma glucose groups for either obese or non-obese subjects.

\section{Discussion}

This study demonstrates certain similarities in the pattern of insulin secretion between Micronesian subjects in Nauru and a Caucasoid population. In both sets, as for Pima Indians [2], the variables age and sex had no significant independent effects on fasting serum CPR. These two variables were excluded from further analysis.

In non-diabetic Micronesian subjects, the variables fasting plasma glucose and body mass index both correlated significantly with fasting serum CPR. As for nondiabetic Caucasoid populations, these variables should be taken into account in interpreting fasting serum CPR levels. Zimmet et al., studying 189 Micronesian subjects, found no correlation between fasting plasma glucose and insulin levels [9]. However, that study did not differentiate between diabetic and non-diabetic subjects. Obesity was shown to be the most important variable influencing fasting insulin levels. In Pima Indians also, obesity was the most significant variable influencing fasting insulin levels, but in that study the variable glucose did have some effect [2]. In a Caucasoid group studied at Busselton, both fasting serum CPR and insulin levels were influenced by obesity and fasting glucose levels. Nevertheless, in both the Busselton group and the Micronesian subjects reported here differences in the degree of obesity were associated with a greater alteration in fasting CPR than were differences in fasting plasma glucose levels.

Unlike a previous study in diabetic Micronesian subjects [9], this study shows increased fasting serum CPR levels with decreasing glucose tolerance (Fig.1). Serum CPR appeared to reach a maximum in the group with 2-h plasma glucose of $15.6-22.1 \mathrm{mmol} / 1$. Multiple 
regression analysis suggested a maximum CPR level at a 2-h plasma glucose level of $20.5 \mathrm{mmol} / 1$. A number of studies have reported an increase and subsequent decrease of insulin response to glucose with decreasing glucose tolerance $[2,10,11]$. A corresponding change in fasting insulin levels has not been reported previously. Interestingly, inspection of the data of Savage et al. suggests that fasting insulin levels might increase and subsequently decrease with increasing 2 -h plasma glucose levels [2]. The decrease appears to occur in the two groups with the highest glucose levels $(>2.2 \mathrm{mmol} / 1$, $400 \mathrm{mg} / 100 \mathrm{ml}$ ).

Mean serum CPR for newly diagnosed diabetic subjects was greater than that for non-diabetic subjects of comparable obesity. Opinions differ on the importance of insulin resistance versus defective insulin secretion in Type 2 diabetes. The evidence now accumulating suggests that, particularly in recent onset diabetes, both fasting and post-glucose serum CPR is greater in the diabetic subject [12]. Defective insulin secretion in the fasting state is clearly not present in the newly-diagnosed Micronesian diabetic subjects. These results support the contention that defective insulin secretion is less important than insulin resistance, particularly in early diabetes [13].

Non-diabetic Micronesian and Caucasoid subjects were matched approximately for fasting plasma glucose levels and obesity. Mean serum CPR levels did not differ significantly in any group. Fasting insulin secretion has not been previously compared in Micronesian and Caucasoid subjects. In other studies, there was no difference in fasting serum insulin levels between Micronesian and Polynesian subjects [3].

Differences have been claimed in both serum insulin and serum CPR levels between Pima Indian and Caucasoid subjects $[14,15]$. However, both these studies dealt with very small numbers of subjects and extension to a larger population may not be valid. In the study reported here, the possible effects of dietary composition or daily joule intake for the two populations have not been taken into account. Fasting serum C-peptide reflects insulin secretion, provided that the metabolic clearance rate of C-peptide is constant. The data reported here suggest that there are no ethnic differences in fasting insulin secretion between Caucasoid and $\mathrm{Mi}$ cronesian subjects.

Acknowledgements. This work was supported in part by grants from the National Health and Medical Research Council of Australia, the Diabetes Research Foundation of Western Australia, Inc., the Government of Nauru and NIH Grant ROI-AM25446.

\section{References}

1. Garcia-Webb $P$, Bonser A, Whiting D (1981) Importance of fasting plasma glucose concentration and obesity in the interpretation of fasting serum C-peptide values. Clin Chim Acta 118: 323-326

2. Savage PJ, Dippe SE, Bennett PH, Gorden R, Roth J, Rushforth NB, Miller M (1975) Hyperinsulinemia and hypoinsulinemia: insulin responses to oral carbohydrate over a wide range of glucose tolerance. Diabetes 24: 362-368

3. Zimmet P, Whitehouse S, Kiss J (1979) Ethnic variability in the plasma insulin response to oral glucose in Polynesian and Micronesian subjects. Diabetes 28: 624-628

4. Waldhäusl W, Bratusch-Marrain P, Gasić S, Korn A, Nowotny P (1982). Insulin production rate, hepatic insulin retention and splanchnic carbohydrate metabolism after oral glucose ingestion in hyperinsulinaemic Type 2 (non-insulin-dependent) diabetes mellitus. Diabetologia 23: 6-15

5. Garcia-Webb P, Bonser A, Wearne KL, Gracey M (1980) Obesity and insulin secretion in fasting high school students. Diabetologia 19: 194-197

6. Faber OK, Binder C, Markussen J, Heding LG, Naithani UK, Kuzuya H, Blix P, Horwitz DC, Rubenstein AH (1978) Characterization of seven C-peptide antisera. Diabetes 27 (Suppl 1): 170-177

7. Nie NH, Hull CH, Jenkins J, Steinbrenner K, Bent DH (1975) Statistical package for the social sciences, 2nd edn, McGraw-Hill, New York

8. National Diabetes Data Group (1979) Classification and diagnosis of diabetes mellitus and other categories of glucose intolerance. Diabetes 28: 1039-1057

9. Zimmet P, Whitehouse S, Alford F, Chisholm D (1978) The relationship of insulin response to a glucose stimulus over a wide range of glucose tolerance. Diabetologia 15:23-27

10. Reaven G, Miller R (1968) Study of the relationship between glucose and insulin response to an oral glucose load in man. Diabetes 17: $560-569$

11. Chiles R, Tzagournis M (1970) Excessive insulin response to oral glucose in obesity and mild diabetes - study of 501 patients. Diabetes $19: 458-464$

12. Malmquist J, Lindgärde F, Eriksson K-F, Johansson E (1982) Plasma insulin and $\mathrm{C}$-peptide in relation to glucose intolerance in middle-aged men. Acta Endocrinol (Copenh) 100: 262-265

13. Reaven GM (1980) Insulin-dependent diabetes mellitus: metabolic characteristics. Metabolism 29: 445-454

14. Arnoff SL, Bennett PH, Gorden P, Rushforth N, Miller M (1977) Unexplained hyperinsulinemia in normal and prediabetic Pima Indians compared with normal Caucasians: an example of racial differences in insulin secretion. Diabetes 26: 827-840

15. Savage PJ, Flock EV, Mako ME, Blix PM, Rubenstein AH, Bennett PH (1979) C-peptide and insulin secretion in Pima Indians and Caucasians: constant fractional extraction over a wide range of insulin concentrations in obesity. J Clin Endocrinol Metab 48: 594-598

Received: 29 September 1983

and in revised form: 22 March 1984

Dr. P.Garcia-Webb

Department of Clinical Biochemistry

Queen Elizabeth II Medical Centre

Perth, W.A. 6009

Australia 